\title{
FORESIGHT TECHNOLOGY FOR THE DEVELOPMENT OF COMPETITIVE ADVANTAGES OF RESORT-RECREATIONAL CLUSTERS
}

\author{
Matvey S. Oborin \\ Perm Institute (Branch) of Russian Economic University named after G. V. Plekhanov, Perm, Russian Federation; \\ Perm State National Research University, Perm, Russian Federation; \\ Perm State Agro-Technological University named after Academician D.N. Pryanishnikov, Perm, Russian Federation; \\ Sochi State University, Sochi, Russian Federation \\ Svetlana Yu. Tsekhla \\ Crimean Federal University named after V.I. Vernadsky, Simferopol, Russian Federation
}

\begin{abstract}
The aim of the study is to adapt the foresight technology to the development of competitive advantages of resort and recreational clusters. The cluster approach has positively proved itself in increasing the efficiency of management of territories with resort and recreational specialization, the formation of prerequisites for the successful functioning of the infrastructure of medical and health tourism, in which the basis is the regional sanatorium and resort complexes.

The expediency of application of foresight technology as an innovative method is based on the experience of modeling of socio-economic space. The principal difference is the system of goal-setting, which is the basis of expert activities, optimization and transformation of the potential of the territories. The advantage of using foresight technology in the formation of competitive clusters of the Republic of Crimea is the possibility of building a network approach, overcoming the natural economic cycle due to the Russian experience of program-target and innovative programming.

The use of foresight technology will contribute to the accelerated pace of development of health clusters in the Republic of Crimea and will have a positive impact on the socio-economic growth of the region.

Key words: resort and recreational cluster, foresight technology, building the future, forecasting, competitive advantage.

Citation. Oborin M.S., Tsekhla S.Yu. Foresight Technology for the Development of Competitive Advantages of Resort-Recreational Clusters. Vestnik Volgogradskogo gosudarstvennogo universiteta. Seriya 3, Ekonomika. Ekologiya [Science Journal of Volgograd State University. Global Economic System], 2019, vol. 21, no. 1, pp. 28-39. (in Russian). DOI: https://doi.org/10.15688/jvolsu3.2019.1.3
\end{abstract}

УДК 338.48

ББК $65.30 ; 65.32$

Дата поступления статьи: 12.01.2019

Дата принятия статьи: 31.01.2019

\section{ФОРСАЙТ-ТЕХНОЛОГИЯ РАЗВИТИЯ КОНКУРЕНТНЫХ ПРЕИМУЩЕСТВ КУРОРТНО-РЕКРЕАЦИОННЫХ КЛАСТЕРОВ}

\section{Матвей Сергеевич Оборин}

Пермский институт (филиал) Российского экономического университета им. Г.В. Плеханова, г. Пермь, Российская Федерация;

Пермский государственный национальный исследовательский университет,

г. Пермь, Российская Федерация;

Пермский государственный аграрно-технологический университет им. академика Д.Н. Прянишникова, г. Пермь, Российская Федерация;

Сочинский государственный университет, г. Сочи, Российская Федерация

\section{Светлана Юрьевна Цехла}

Крымский федеральный университет им. В.И. Вернадского, г. Симферополь, Российская Федерация 
Аннотация. Целью исследования является адаптация форсайт-технологии к развитию конкурентных преимуществ курортно-рекреационных кластеров. Кластерный подход положительно зарекомендовал себя в повышении эффективности управления территориями с курортно-рекреационной специализацией, формировании предпосылок к успешному функционированию инфраструктуры лечебно-оздоровительного туризма, в которой основой являются региональные санаторно-курортные комплексы.

Обоснована целесообразность применения форсайт-технологии как инновационного метода формирования будущего исходя из опыта моделирования социально-экономического пространства. Принципиальным отличием является система целеполагания, положенная в основу экспертной деятельности, оптимизации и преобразования потенциала территорий. Преимущество применения форсайт-технологии в формировании конкурентоспособных кластеров Республики Крым заключается в возможности построения сетевого подхода, преодоления естественного экономического цикла за счет российского опыта программноцелевого и инновационного программирования.

Применение форсайт-технологии будет способствовать ускоренным темпам развития лечебно-оздоровительных кластеров на территории Республики Крым и благоприятно отразится на социально-экономическом росте показателей региона.

Ключевые слова: курортно-рекреационный кластер, форсайт-технология, построение будущего, прогнозирование, конкурентное преимущество.

Цитирование. Оборин М. С., Цехла С. Ю. Форсайт-технология развития конкурентных преимуществ курортно-рекреационных кластеров // Вестник Волгоградского государственного университета. Серия 3 , Экономика. Экология. - 2019. - Т. 21, № 1. - C. 28-39. - DOI: https://doi.org/10.15688/jvolsu3.2019.1.3

\section{Введение}

В условиях экономических кризисов кластерный подход зарекомендовал себя как эффективный инструмент регионального развития. Необходимость системного преобразования территории и инфраструктуры способствовала становлению ведущей роли государства в качестве субъекта кластерной политики в России, внедрению научно обоснованного планирования, сочетающего отечественные и зарубежные подходы, адаптации положительного опыта $[8 ; 9 ; 2]$.

Одной из инновационных технологий преобразования объекта управления является форсайт. Форсайт-технология за рубежом один из основных способов определения перспективных направлений развития деятельности территорий и предприятий. В настоящее время данная технология получила широкое распространение и в России, в первую очередь на национальном уровне.

Применение форсайта связано с внедрением технического прогресса и прорывным государственным развитием, основанным на комплексном подходе к формированию будущего с учетом изменений в экономической, социальной, научной, культурной областях.

Форсайт - это систематическая попытка заглянуть в долгосрочное будущее науки, технологии, экономики и общества для иден- тификации зон стратегического исследования и возникновения родовых технологий, которые образуют возможность приносить масштабные экономические и социальные выгоды. Отличительной особенностью является прогнозирование, направленное на определение стратегически важных зон развития территории, в том числе курортно-рекреационных кластеров $[3 ; 4 ; 6]$.

Рассмотрим несколько определений термина «форсайт»:

- систематический совместный процесс построения будущего на основе стратегии и координации совместных действий (FOREN Guide);

- систематические попытки заглянуть в будущее науки, общества, экономики и технологий в целях гармоничного развития (Asia-Pacific Economic Cooperation - Center for Technology Foresight);

- формализованная методика оценки долгосрочных последствий реализуемых решений в сференауки и технологий (Technology and Innovation Foresight for Bulgaria and Romania - ForeTech); - систематическое размышление о будущем и воздействие на него (Australian Center for Innovation).

В основном форсайт-технологии направлены на прогнозирование будущего. Однако этот метод планирования содержит в себе ряд элементов, которые отличают его от прогнозирования, например: 
1) совокупность мнений экспертов-представителей различных основных сторон общества - стейкхолдеров. Их мнение учитывается также при формировании форсайтом конкурентных преимуществ;

2) определение главных направлений деятельности региона (предприятия, другого субъекта) по приоритетам стейкхолдеров.

\section{Постановка задачи}

Недооценка потенциала санаторно-курортного комплекса как базы развития лечебно-оздоровительных услуг влияет на эффективность использования курортно-рекреационного потенциала регионов страны, низкий вклад в региональный валовой продукт. Для регионов Южного федерального округа повышение эффективности деятельности предприятий санаторно-курортного комплекса является актуальным направлением, поскольку регионы имеют традиционно сильные позиции в туристско-рекреационной деятельности.

\section{Методы исследования}

Системный подход заключается в комплексной оценке влияния предприятий санатор- но-курортного комплекса как сферы услуг лечебно-оздоровительного туризма на стратегию социально-экономического развития региона.

Ситуационный анализ состоит в учете факторов и условий, оказывающих воздействие на объект исследования в данный период: состояние отрасли, наличие структурных и финансовых проблем, разработка новых направлений повышения эффективности деятельности.

Формально-логический метод направлен на выявление причинно-следственной связи между изучаемым объектом и социально-экономическими показателями территориального развития и устойчивого роста экономики, выявление наиболее перспективных направлений повышения эффективности деятельности санаторно-курортного комплекса.

\section{Обсуждение результатов}

Инструментарий форсайт-технологии включает в себя как классические методы прогнозирования и анализа, так и абсолютно новые для этого типа прогнозирования. Детальное применение форсайта обусловлено стратегическими целями и задачами развития территорий с курортно-рекреационной специализацией (рис. 1).

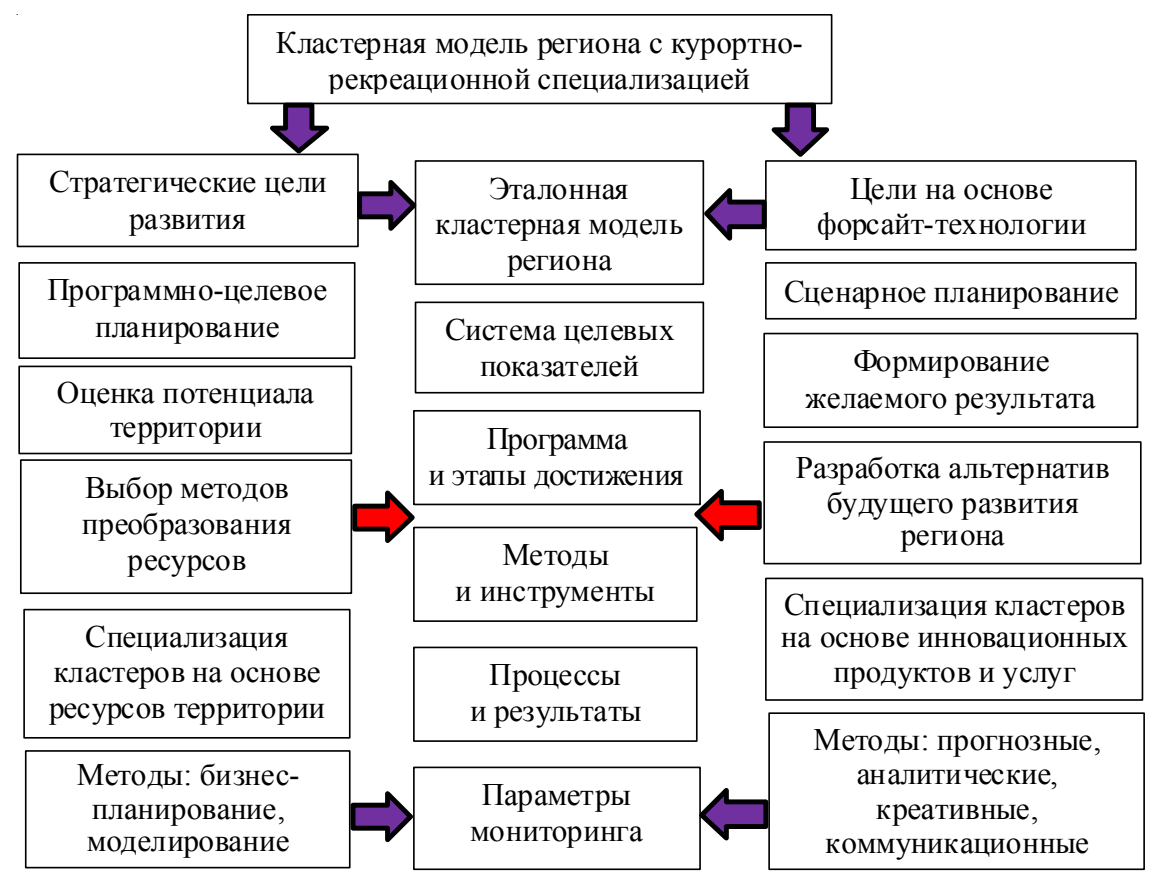

Рис. 1. Роль форсайт-технологии в формировании кластерной модели развития региона с курортно-рекреационной специализацией

Примечание. Разработано авторами. 
Более подробно стоит рассмотреть самые востребованные и эффективные креативные методы форсайт-технологии [10]:

1. Сценирование. Является одним из самых старых и популярных методов. Оно предполагает формирование двух и более развернутых вариантов развития будущего кластеpa, каждый из которых может возникнуть при выполнении определенного набора условий. Отличие сценирования от классических методов в том, что оно полностью строится на воображаемых ситуациях. Практически сценирование является совокупностью альтернативных текстов, которые выстроены вокруг избранных плоттерных точек.

2. Разработка будущего (futures workshops). Является инструментом проектирования. По своей сути разработка будущего схожа со сценированием, но предполагает формирование не множества альтернатив, а картины единственно идеального желаемого будущего и его плана реализации на практике.

3. Метод Дельфи. Метод форсайт-технологии, применяющийся для экспертизы и прогнозирования. Его суть заключается в структурировании и организации процесса групповой коммуникации, который направлен на формирование условий для эффективной деятельности группы экспертов, ориентированной на решение комплексной проблемы. Метод Дельфи использует повторяющиеся независимые опросы ряда экспертов, которые помогают в определении вероятности возникновения, значения и последствий факторов, событий и тенденций, которые связаны с комплексной проблемой. Преимущество данного метода заключается в возможности выработки развернутых, прозрачных и объективных результатов, которые не подвержены влиянию авторитетных участников обсуждений.

4. Картирование технологий. Объединяет в себе целый класс интеллектуальных методик, которые позволяют спрогнозировать развитие инновационных технологий. Этот метод проектирует план-сценарий развития технологий визуально в виде «карты», отмечает на этой «карте» вероятности и точки критических решений.

Проведение методов форсайт-технологии происходит поэтапно. Всего насчитывается 3 таких этапа:
1. Предфорсайт. На этом этапе организаторы процесса форсайта - стейкхолдеры и потребители его конечного результата формируют цели и задачи, источники финансирования технологии. Предфорсайт отличается осуществлением характеристики условий проведения исследования, анализа внутренней и внешней среды курортно-рекреационного кластера, установкой показателей форсайта.

2. Форсайт. Этот этап характеризуется совокупной деятельностью организационных институтов, экспертов, которые занимаются разработками в курортно-рекреационной сфере; здесь также исследуются перспективы развития кластера, выделяются конкурентные преимущества, подготавливаются все необходимые промежуточные и итоговые документы, проводятся семинары и обсуждения.

3. Постфорсайт. На этом этапе проводится мониторинг возможных изменений будущего, осуществляются контроль за реализацией разработанных сценариев развития процесса и проведение повторных этапов исследования.

Схема реализации трех этапов по формированию кластерной модели развития региона с курортно-рекреационной специализацией на примере Республики Крым представлена на рисунке 2.

Курортно-рекреационные кластеры как объединения, обладающие единой системой взаимосвязанных и взаимодействующих субъектов и осуществляющие деятельность в сферах туризма, отдыха и здравоохранения, формируются на основе ресурсов. Территории, которые обладают соответствующим природно-климатическим потенциалом, являются основой модели кластерного развития. Такие ресурсы обычно представляют собой как естественные, так и искусственные образования: уникальные минеральные и грязевые источники, археологические и исторические памятники, природные заповедники, а также инновационные технологии в области медицины, туризма и курортного дела. Все эти ресурсы в рамках курортно-рекреационного кластера можно охарактеризовать как основу формирования предложения и конкурентного преимущества кластера.

Конкурентные преимущества кластера это приоритет над территорией конкурентов в различных отраслях деятельности кластера, 
выражающийся в достаточной концентрации уникальных (приоритетных) ресурсов и благоприятных климатических, инфраструктурных и технологических характеристик. Конкурентные преимущества определяются их относительностью (когда один тип ресурсов дает приоритет только одной территории) и подверженностью воздействию различных факторов (неконтролируемое влияние внешних факторов может быть как положительным, так и отрицательным).

В свете неоднородности конкурентных преимуществ курортно-рекреационного класте$\mathrm{pa}$, а также неопределенности влияния на его деятельность внешних и внутренних факторов применение форсайт-технологии для создания таких преимуществ является оптимальным способом повышения конкурентоспособности территории кластера и роста эффективности использования рекреационных ресурсов.

Формирование конкурентных преимуществ курортно-рекреационных кластеров с помощью форсайт-технологии имеет следующие особенности:

1) определение возможных вариантов развития деятельности кластеров;
2) формирование главной группы преимуществ кластера (те из них, которые будут удовлетворять потребности большинства);

3) разработка последовательности методов достижения избранных конкурентных преимуществ [7].

Форсайт-технология определения конкурентных преимуществ кластера рекреационной направленности основывается также на степени эффективности взаимодействия субъектов кластера. Их формы сотрудничества оказывают влияние на появление новых конкурентных преимуществ. Формы сотрудничества между участниками кластерного образования в курортно-рекреационной сфере можно классифицировать по таким признакам, как:

1) типы сотрудничества - интеграция, кооперация, формальное взаимодействие на основе положений согласованного договора;

2) отраслевая принадлежность субъектов - межотраслевые и внутриотраслевые типы взаимодействия;

3) масштаб субъектов - разделение по крупным, средним и малым предприятиям;

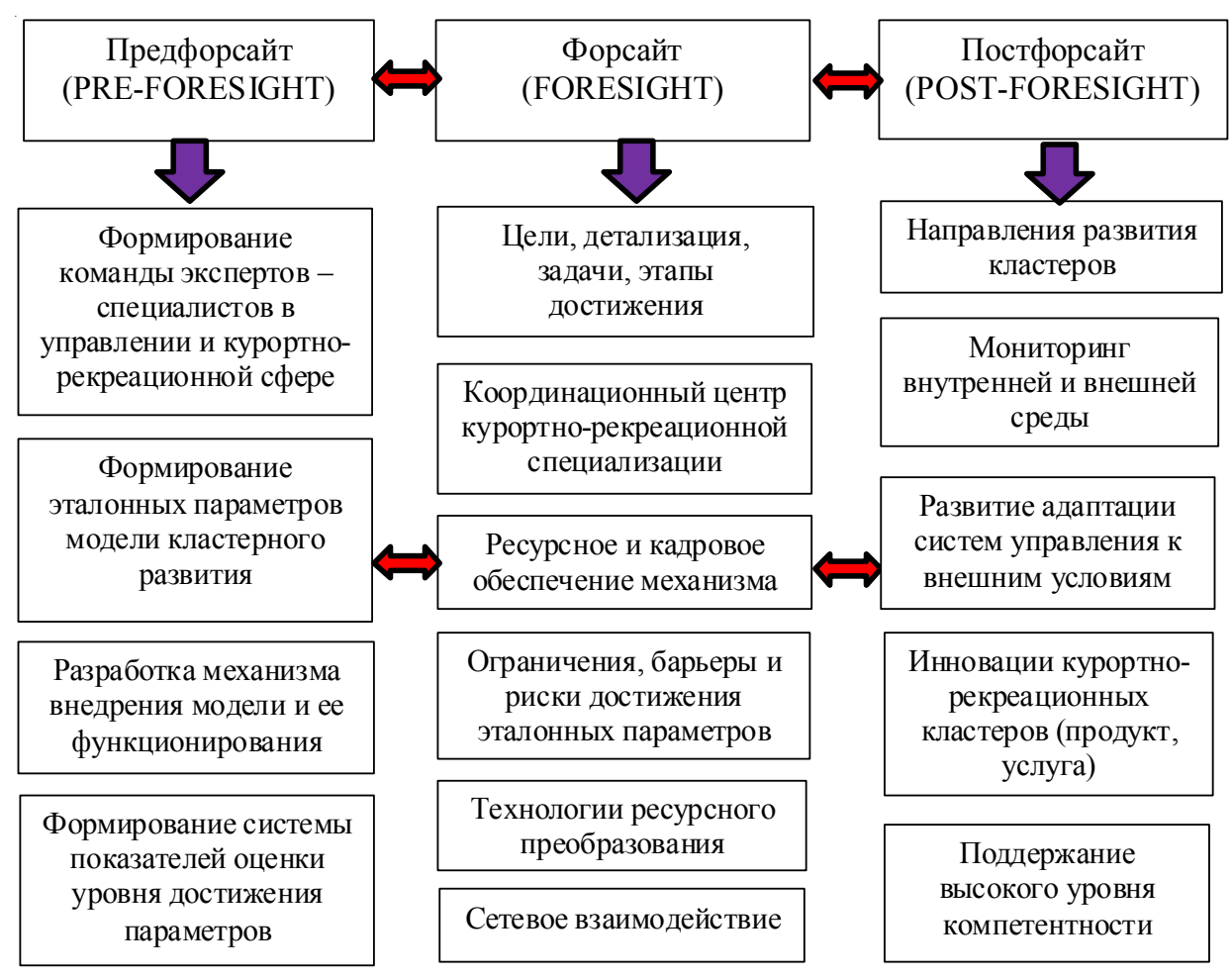

Рис. 2. Этапы проведения форсайта по формированию кластерной модели развития Республики Крым Примечание. Разработано авторами. 
4) направления существующих взаимодействий - вертикальное, горизонтальное, смешанное;

5) степень тесноты имеющихся взаимосвязей - самостоятельные независимые и родственные предприятия и организации;

6) функциональные сферы взаимодействия - это могут быть отрасли маркетинга, финансирования, управления, общий технологический процесс осуществления санаторнокурортных услуг и так далее;

7) виды взаимодействия - административное, технологическое, финансово-экономическое;

8) степень устойчивости взаимосвязей субъектов - устойчивое (стабильное) и неустойчивое взаимодействие;

9) модели взаимодействия - стратегические альянсы, франчайзинг, аутсорсинг и другие [14].

Форсайт-технологии в курортно-рекреационной сфере способствуют определению основных конкурентных преимуществ регионов. Это происходит в процессе установления различных вариантов будущего (например, при использовании методов сценирования и картирования) либо единого направления развития (метод развития будущего). Форсайт-технологии в санаторно-курортных кластерах формируют также цели и задачи на долгосрочную перспективу (сроком приблизительно 10 лет), помогают в создании вектора для его инновационного развития. Основываясь на данных по Республике Крым и Краснодарскому краю, сравним их конкурентные преимущества, которые были выявлены в прошлом форсайт-технологией, и рассмотрим последствия принятых решений, угрозы и возможности конкурентных преимуществ курортно-рекреационных кластеров в этих регионах.

Концепция Федеральной целевой программы «Развитие внутреннего и въездного туризма в Российской Федерации (20192025 годы)» предусматривает использование кластерного подхода в качестве инструмента стратегического развития туризма с акцентом на усиление его роли как фактора повышения качества жизни населения страны и регионов. Изменения в части программно-целевого подхода касаются определения приоритетного вида туризма в рамках созда- ваемого кластера в регионе, реализация кластерного развития территорий в соответствии с наибольшим вкладом в экономические и социальные показатели.

Регионы Краснодарский край и Республика Крым включены в перспективный туристский укрупненный инвестиционный проект «Черноморское побережье». Рассматриваемая Концепция содержит предложения по опережающему развитию Республики Крым. В частности, кластерный подход признается основным механизмом комплексного преобразования курортов и лечебно-оздоровительных местностей, основным видом туризма обозначен лечебно-оздоровительный, основанный на развитом санаторно-курортном комплексе, диверсифицированных лечебно-оздоровительных услугах высокого качества.

В 2016-2017 гг. Краснодарский край принял свыше 15 млн и 15,8 млн туристов соответственно, Республика Крым - около 6 млн и 5,4 млн туристов за аналогичные периоды.

Основным достоинством Краснодарского края является рекреационно-туристический потенциал, который включает 18 курортно-рекреационных территорий и преимущественно сосредоточен в городах-курортах федерального значения (Сочи, Анапа, Туапсе, Геленджик) и других городах и районах. Кроме Черного моря на юго-западе Краснодарский край омывается Азовским морем на северо-западе. Уникальные для России природно-климатические условия края, наличие передовых оздоровительных учреждений и технологий, объектов исторического и культурного наследия предоставляют возможности для создания высокоэффективного, конкурентоспособного туристско-рекреационного комплекса международного уровня, который придаст позитивный имидж стране на международной арене и обеспечит растущие потребности населения в отдыхе, лечении, туризме и связанных с этим услугах.

С 2015 г. в рамках федеральной целевой программы «Социально-экономическое развитие Республики Крым и г. Севастополя до 2020 года» осуществляется финансирование создания на территории Республики Крым туристско-рекреационных кластеров: «Детский отдых и оздоровление» (г. Евпатория); «Лечебно-оздоровительный отдых» (г. Саки); в 
районе озера Чокракское (Ленинский р-н, п. Курортное); «Черноморский» (Черноморский р-н); «Коктебель» (пгт Коктебель).

Краснодарский край традиционно относится к регионам-лидерам в сфере туристско-рекреационной деятельности, сравнительный анализ показателей туристско-рекреационной деятельности субъектов страны представлен в таблице 1.

Показатели Краснодарского края в абсолютном выражении значительно опережа- ют показатели Республики Крым, общей тенденцией является сохранение убытка.

Согласно направлениям Стратегий развития Республики Крым и Краснодарского края их основные конкурентные преимущества заключаются в рекреационных ресурсах и транспортной инфраструктуре. Полный обзор конкурентных преимуществ рассматриваемых регионов представлен в таблице 2 .

Рассмотрим наиболее важные для курортно-рекреационного кластера конкурентные

Экономические показатели туристско-рекреационной деятельности Краснодарского края и Республики Крым за 2016-2017 гг.

\begin{tabular}{|c|c|c|c|c|c|c|}
\hline \multirow{2}{*}{ Показатель } & \multicolumn{2}{|c|}{ Россия } & \multicolumn{2}{|c|}{ Краснодарский край } & \multicolumn{2}{|c|}{ Республика Крым } \\
\hline & 2016 г. & 2017 г. & 2016 г. & 2017 г. & 2016 г. & 2017 г. \\
\hline $\begin{array}{l}\text { Численность санаторно-курортных } \\
\text { организаций, единиц }\end{array}$ & 1832 & 1849 & 206 & 189 & 111 & 111 \\
\hline $\begin{array}{l}\text { Доходы санаторно-курортных орга- } \\
\text { низаций, млн руб. }\end{array}$ & 138111 & 136184 & 34360 & 32511 & 9181 & 11278 \\
\hline $\begin{array}{l}\text { Затраты санаторно-курортных орга- } \\
\text { низаций, млн руб. }\end{array}$ & 166372 & 146516 & 45363 & 32600 & 10252 & 12313 \\
\hline $\begin{array}{l}\text { Численность коллективных средств } \\
\text { размещения, единиц }\end{array}$ & 20534 & 25291 & 3106 & 4641 & 1134 & 1257 \\
\hline $\begin{array}{l}\text { Доходы коллективных средств раз- } \\
\text { мещения, млн руб. }\end{array}$ & 70583 & 69381 & 8629 & 9002 & 999 & 1171 \\
\hline $\begin{array}{l}\text { Затраты коллективных средств раз- } \\
\text { мещения, единиц, млн руб. }\end{array}$ & 442776 & 438899 & 87751 & 74224 & 18521 & 19130 \\
\hline
\end{tabular}

Примечание. Составлено авторами по: $[1 ; 5 ; 10-13]$.

Таблийа 1

\section{Конкурентные преимущества курортно-рекреационной сферы Республики Крым и Краснодарского края}

Таблица 2

\begin{tabular}{|c|c|}
\hline Республика Крым & Краснодарский край \\
\hline Действующая туристско-рекреационная инфраструктура & $\begin{array}{l}\text { Большой внутренний туристический рынок } \\
\text { (ежегодно принимает свыше } 5 \text { млн туристов) }\end{array}$ \\
\hline Транспортно-транзитный потенциал & $\begin{array}{l}\text { Транспортно-логистический хаб, соединяющий все } \\
\text { регионы Южного полюса роста }\end{array}$ \\
\hline Высокий уровень человеческого потенциала & Широкий выбор административных ресурсов \\
\hline $\begin{array}{l}\text { Климатический и ресурсный потенциал для развития } \\
\text { сельскохозяйственного, строительного и химического } \\
\text { производства }\end{array}$ & Высокая предпринимательская активность \\
\hline Минерально-ресурсный потенциал & Высокий потенциал развития «умной экономики» \\
\hline $\begin{array}{l}\text { Комфортные климатические условия для санаторно- } \\
\text { курортной деятельности }\end{array}$ & $\begin{array}{l}\text { Богатые природные ресурсы, эффективно } \\
\text { используемые на практике }\end{array}$ \\
\hline $\begin{array}{l}\text { Стратегически важные и перспективные геополитическое } \\
\text { и геоэкономическое положения }\end{array}$ & $\begin{array}{l}\text { Уникальное геостратегическое положение - } \\
\text { пересечение логистических, торговых и } \\
\text { транспортных потоков }\end{array}$ \\
\hline $\begin{array}{l}\text { Ресурсная, финансовая и институциональная поддержка в } \\
\text { связи со вступлением в РФ }\end{array}$ & Высокая степень развития инфраструктуры \\
\hline $\begin{array}{l}\text { Возникновение межрегиональных производственно- } \\
\text { кооперационных связей с субъектами РФ }\end{array}$ & Повышенная инвестиционная привлекательность \\
\hline Экологическая чистота продуктов питания & Развитая кредитно-финансовая инфраструктура \\
\hline
\end{tabular}

Примечание. Составлено авторами по: [1; 5; 10-13]. 
преимущества Республики Крым в сравнении с Краснодарским краем, среди которых туристско-рекреационная инфраструктура, транспортная инфраструктура и экологические и климатические условия регионов.

Первое важное конкурентное преимущество, которое в схожей степени присуще Республике Крым и Краснодарскому краю, - это туристско-рекреационная инфраструктура. По этому показателю регионы обладают приоритетом в разных аспектах деятельности. Данные конкурентного показателя представлены в таблице 3.

Очевидно, что Краснодарский край по данному показателю опережает Республику Крым. Это объясняется тем, что инфраструктура Крыма находится на стадии развития с 2014 г. - времени вступления в состав Российской Федерации. Согласно агентству «Spark-Interfax» с каждым годом общее количество гостиниц и предприятий общественного питания как в Республике Крым, так и в Краснодарском крае, возрастает. Большую часть от всех подобных учреждений составляют индивидуальные предприниматели, их доля в общем объеме рынка - около $65 \%$ и $62 \%$ (соответственно) ежегодно. По организационно-правовой форме из всех коммерческих юридических лиц подавляющее преимущество имеют общества с ограниченной ответственностью. Государственные унитарные предприятия субъектов РФ обладают наименьшей долей рынка - с 2014 по 2016 гг. были зарегистрированы всего 3 такие компании в Республике Крым и 2 - в Краснодарском крае.

Следующий конкурентный показатель, требующий рассмотрения, - это развитие транспортной инфраструктуры. Данные по его основным элементам отображены в таблице 4.

Согласно данным агентства «Риа-Рейтинг» Краснодарский край за последние три года входил в топ-5 по показателю наилучшего покрытия автомобильных дорог в России. Республика Крым в сравнении с этим находится в четвертом десятке (опустилась на 10 позиций по отношению к 2015 году). Стоит от-

Таблица 3

Количество предприятий гостиничного типа и общественного питания, Республика Крым и Краснодарский край, шт.

\begin{tabular}{|c|c|c|c|c|c|c|}
\hline \multirow{2}{*}{ Тип } & PK & KK & PK & KK & PK & KK \\
\hline & \multicolumn{2}{|c|}{2015 г. } & \multicolumn{2}{|c|}{2016 г. } & \multicolumn{2}{|c|}{2017 г. } \\
\hline Коммерческие юридические лица & 1688 & 5769 & 1834 & 5776 & 1882 & 5610 \\
\hline \multicolumn{7}{|l|}{ Из них: } \\
\hline Общества с ограниченной ответственностью & 1653 & 5662 & 1798 & 5674 & 1846 & 5514 \\
\hline Муниципальные унитарные предприятия & 14 & 13 & 15 & 13 & 15 & 12 \\
\hline Непубличные акционерные общества & 12 & 58 & 12 & 57 & 12 & 56 \\
\hline Производственные кооперативы & 5 & - & 5 & - & 5 & - \\
\hline $\begin{array}{l}\text { Государственные унитарные предприятия } \\
\text { субъектов РФ }\end{array}$ & 3 & 2 & 3 & 2 & 3 & 2 \\
\hline Публичные акционерные общества & 1 & 17 & 1 & 16 & 1 & 15 \\
\hline Индивидуальные предприятия & 2470 & 8655 & 2815 & 9255 & 3446 & 9613 \\
\hline Всего & 4166 & 14424 & 4657 & 15031 & 5336 & 15223 \\
\hline
\end{tabular}

Примечание. Составлено авторами по: [1; 5; 10-13]. РК - Республика Крым; КК - Краснодарский край.

Таблииа 4

Позиции Республики Крым и Краснодарского края в рейтинге по показателю «Освоенность территории и развитие транспортной инфраструктуры», 2015-2017 гг.

\begin{tabular}{|l|c|c|c|c|c|c|}
\hline \multirow{2}{*}{ Показатель } & РК & КК & PК & \multicolumn{2}{c|}{ КК } & \multicolumn{2}{c|}{ РК } & КК \\
\cline { 2 - 9 } & \multicolumn{2}{|c|}{2015 г. } & \multicolumn{2}{|c|}{2016 г. } & \multicolumn{2}{|c|}{2017 г. } \\
\hline Плотность автомобильных дорог общего пользования & 20 & 24 & 15 & 23 & 16 & 21 \\
\hline $\begin{array}{l}\text { Доля автомобильных дорог общего пользования, соот- } \\
\text { ветствующая нормативным требованиям }\end{array}$ & 23 & 3 & 37 & 2 & 35 & 4 \\
\hline Плотность железнодорожных путей общего пользования & 17 & 13 & 17 & 13 & 17 & 13 \\
\hline
\end{tabular}

Примечание. Составлено авторами по: $[1 ; 5 ; 10-13]$. 
метить, что плотность железнодорожных путей как в Крыму, так и в Краснодарском крае, находится приблизительно на одном уровне 17 позиция против 13 соответственно.

Природные условия являются важным конкурентным преимуществом южных регионов в организации деятельности курортно-рекреационного кластера: Позиции Республики Крым и Краснодарского края по экологическому показателю представлены в таблице 5.

Данные агентства «Риа-Рейтинг» показывают, что по уровню благоприятности климата регионов Республика Крым и Краснодарский край оценены наивысшим баллом. Это говорит об их схожих климатических ус- ловиях, на базе которых возможно создание и развитие равнозначных санаторно-курортных кластеров. Однако нужно отметить и ситуацию объемов вредных выбросов в атмосферу - Крым является более «чистым» регионом по сравнению с Краснодарским краем изза отсутствия на его территории многих видов промышленности.

С учетом проведенного анализа сформируем модель развития конкурентных преимуществ курортно-рекреационных кластеров Республики Крым (рис. 3).

В результате реализации форсайт-технологии развитие курортно-рекреационных кластеров Республики Крым будет осуществ-

\section{Позиции Республики Крым и Краснодарского края в рейтинге по показателю «Экологические и климатические условия», 2015-2017 гг.}

\begin{tabular}{|l|c|c|c|c|c|c|}
\hline \multicolumn{1}{|c|}{ Показатель } & РК & КК & РК & КК & РК & КК \\
\cline { 2 - 7 } & \multicolumn{2}{|c|}{2015 г. } & \multicolumn{2}{|c|}{2016 г. } & \multicolumn{2}{|c|}{2017 г. } \\
\hline $\begin{array}{l}\text { Доля выбросов в атмосферу загрязняющих веществ (на } \\
\text { единицу площади населенных пунктов) }\end{array}$ & 3 & 41 & 4 & 43 & 4 & 43 \\
\hline Оценка климата & 1 & 1 & 1 & 1 & 1 & 1 \\
\hline $\begin{array}{l}\text { Расходы на охрану атмосферного воздуха (на единицу вы- } \\
\text { бросов) }\end{array}$ & 74 & 51 & 56 & 48 & 45 & 49 \\
\hline
\end{tabular}

Примечание. Составлено авторами по: [1; 5; 10-13].

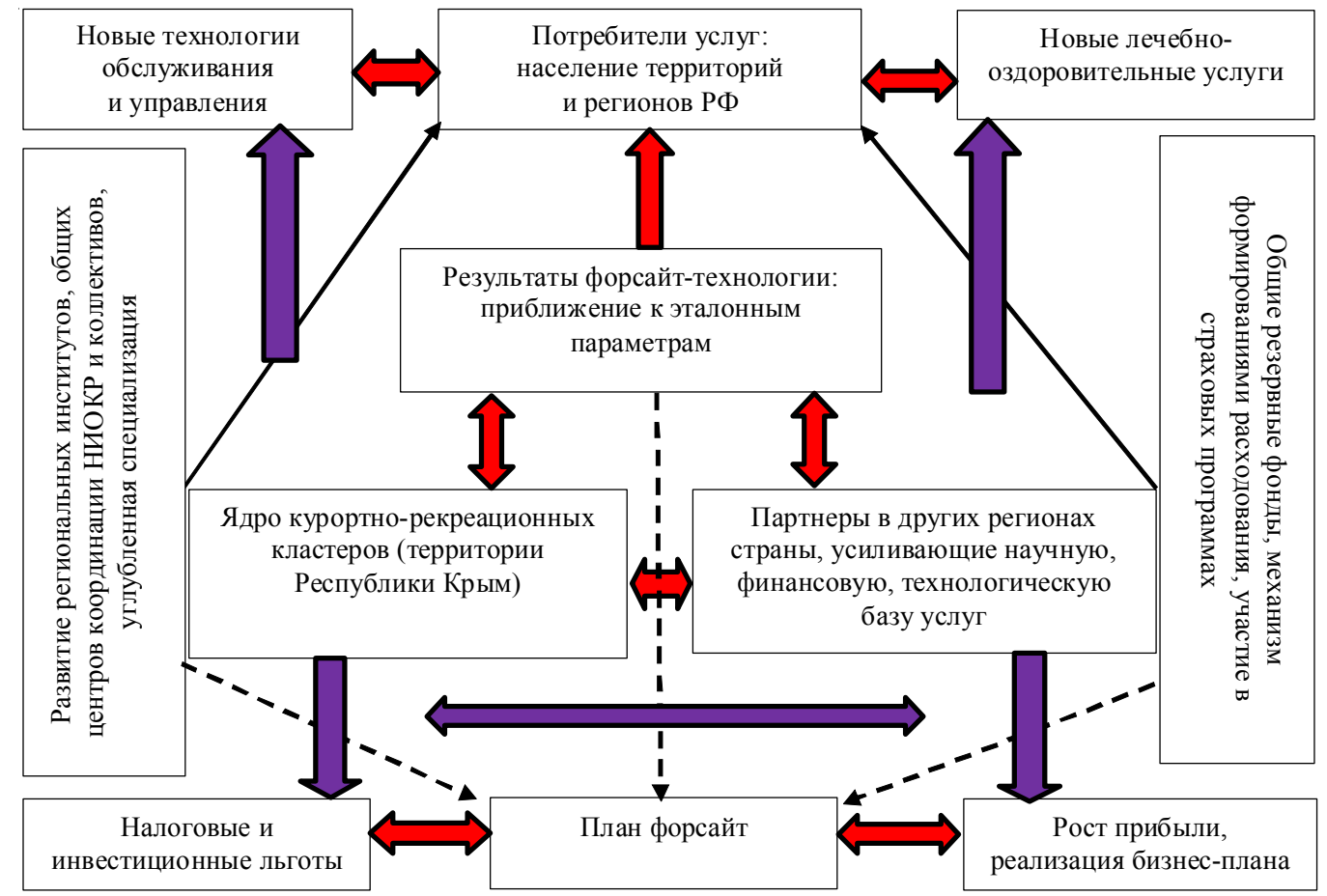

Рис. 3. Модель развития конкурентных преимуществ курортно-рекреационных кластеров Республики Крым на основе форсайт-технологии

Примечание. Разработано авторами. 
ляться более высокими темпами, приближая показатели к эталонным параметрам. Полученные конкурентные преимущества - новые технологии обслуживания и управления, новые лечебно-оздоровительные услуги - будут реализованы за счет обмена опытом и повышения ключевых компетенций, оптимизации ресурсов и роста их качества.

\section{Вывод}

Таким образом, форсайт - это прогноз, который нацелен на определение стратегически важных зон развития территории. Форсайттехнологии создания конкурентных преимуществ курортно-рекреационных кластеров заключаются, прежде всего, в создании одного или нескольких вариантов развития будущих событий в санаторно-курортной, экономической и социальной сферах деятельности. Такие варианты разрабатываются экспертами-представителями - стейкхолдерами, которые могут влиять на процесс определения конкурентных преимуществ при их рассмотрении. Выявленные в процессе осуществления этапов форсайта (предфорсайт, форсайт и стадия постфорсайта) конкурентные преимущества способствуют эффективному развитию курортно-рекреационных кластеров. Это показывает и пример Республики Крым, которая после вступления в состав РФ в 2014 г. обрела дополнительные конкурентные преимущества, позволяющие ей занимать высокие позиции по отдельным курортно-рекреационным параметрам, привлекая новых туристов и потребителей санаторно-курортных услуг, а также составляя конкуренцию кластерам Краснодарского края.

В настоящих условиях форсайт-технология способна обеспечить для Республики Крым качественное преобразование курортно-рекреационной сферы, становление региона технологической платформой России в области курортной медицины на основе цифровых лечебно-оздоровительных технологий.

\section{СПИСОК ЛИТЕРАТУРЫ}

1. Анализ социально-экономического, ресурсного и экологического состояния Республики Крым,
Приложение 1. - Электрон. текстовые дан. - Режим доступа: https://minek.rk.gov.ru/file/File/2015/docs/ strateg/strateg_konc/strateg_pr1.pdf. - Загл. с экрана.

2. Влияние природных лечебных ресурсов на развитие санаторно-курортной деятельности региона / Оборин М. С. [и др.] // Фундаментальные исследования. - 2014. - № 9-4. - С. 823-827.

3. Калюжнова, Н.Я. Способы влияния форсайта на развитие инновационной деятельности / Н. Я. Калюжнова, Е. В. Верхотурова // Вестник Иркутского государственного технического университета. - 2014. - № 4 (87). - С. 186-193.

4. Калюжнова, Н. Я. Форсайт-технология как инструмент прогнозирования инновационного развития регионов / Н. Я. Калюжнова, Е. В. Верхотурова // Фундаментальные исследования. - 2013. № 6. - C. 62-73.

5. Компании Республики Крым - статистика организаций, каталог и рейтинг топ компаний. Электрон. текстовые дан. - Режим доступа: http://www.sparkinterfax.ru/ru/statistics/region/35000000000. - Загл. с экрана.

6. Крюков, С. В. Форсайт: от прогноза к формированию будущего / С. В. Крюков // Terra Economicus. -2010. - T. 8, № 3 (ч. 2). - C. 8-14.

7. Максимов, Д. А. Форсайт как инновационный инструмент развития строительной организации / Д. А. Максимов // IX Всерос. конф. «Молодежь и наука», 2013 г. - Электрон. текстовые дан. Режим доступа: http://elib.sfu-kras.ru/handle/2311/ 11384. - Загл. с экрана.

8. Оборин, М. С. Динамика развития санаторно-курортного комплекса и лечебно-оздоровительного туризма в Пермском крае / М. С. Оборин // Вестник Удмуртского университета. Серия: Биология. Науки о земле. - 2013. - № 4. - С. 146-153.

9. Оборин, М. С. Методологические аспекты проведения системного анализа и кластеризации рынка санаторно-курортных услуг / М. С. Оборин // Научные ведомости Белгородского государственного университета. Серия: Экономика. Информатика. - 2015. - № 19 (216). - С. 43-51.

10. Рейтинг регионов РФ по качеству жизни 2015. - Электрон. текстовые дан. - Режим доступа: http://vid1.rian.ru/ig/ratings/life_2015.pdf. - Загл. c экрана.

11. Рейтинг регионов РФ по качеству жизни 2016. - Электрон. текстовые дан. - Режим доступа: http://vid1.rian.ru/ig/ratings/life_2016.pdf. - Загл. c экрана.

12. Рейтинг регионов РФ по качеству жизни 2017. - Электрон. текстовые дан. - Режим доступа: http://vid1.rian.ru/ig/ratings/life_2017.pdf. - Загл. c экрана.

13. Стратегия социально-экономического развития Краснодарского края на долгосрочный период, 
версия 1.1 (полная). - Электрон. текстовые дан. - Peжим доступа: http://mprkk.ru/media/main/attachment/ attach/proekt_strategii.pdf. - Загл. с экрана.

14. Яковлева-Чернышева, А. Ю. Особенности кластерного взаимодействия в санаторно-курортной сфере / А. Ю. Яковлева-Чернышева // Управление и экономика в XXI веке. -2014. - № 2. - С. 23-29.

\section{REFERENCES}

1. Analiz sotsialno-ekonomicheskogo, resursnogo i ekologicheskogo sostoyaniya Respubliki Krym, Prilozhenie 1 [Analysis of the Socio-Economic, Resource and Environmental Status of the Republic of Crimea, Appendix 1]. URL: https://minek.rk.gov.ru/file/ File/2015/docs/strateg/strateg_konc/strateg_pr1.pdf.

2. Oborin M.S., et al. Vliyanie prirodnykh lechebnykh resursov na razvitie sanatorno-kurortnoy deyatelnosti regiona [The Influence of Natural Medicinal Resources on the Development of Sanatorium-Resort Activity of the Region]. Fundamentalnye issledovaniya, 2014, no. 9-4, pp. 823-827.

3. Kalyuzhnova N.Ya., Verkhoturova E.V. Sposoby vliyaniya forsayta na razvitie innovatsionnoy deyatelnosti [The Ways of Foresight Influence on the Development of Innovative Activity]. Vestnik Irkutskogo gosudarstvennogo tekhnicheskogo universiteta, 2014, no. 4 (87), pp. 186-193.

4. Kalyuzhnova N.Ya., Verkhoturova E.V. Forsayttekhnologiya kak instrument prognozirovaniya innovatsionnogo razvitiya regionov [Foresight Technology as a Tool for Forecasting Innovative Development of Regions]. Fundamentalnye issledovaniya, 2013, no. 6, pp. 62-73.

5. Kompanii Respubliki Krym - statistika organizatsiy, katalog $i$ reyting top kompaniy [Companies of the Republic of Crimea - Statistics of Organizations, Catalog and Rating of Top Companies]. URL: http://www.spark-interfax.ru/ru/statistics/region/ 35000000000 .

6. Kryukov S.V. Forsayt: ot prognoza k formirovaniyu budushchego [Foresight: from Forecast to Shaping the Future]. Terra Economicus, 2010, vol. 8, no. 3 (part 2), pp. 8-14.

7. Maksimov D.A. Forsayt kak innovatsionnyy instrument razvitiya stroitelnoy organizatsii [Foresight as an Innovative Tool for the Development of a Construction Organization]. IX Vseros. konf. "Molodezh i nauka», $2013 \mathrm{~g}$. [The $9^{\text {th }}$ All-Russian Conference "Youth and Science", 2013]. URL: http:// elib.sfu-kras.ru/handle/2311/11384.

8. Oborin M.S. Dinamika razvitiya sanatornokurortnogo kompleksa i lechebno-ozdorovitelnogo turizma v Permskom krae [Dynamics of the Development of a Sanatorium-ResortComplex and Health Tourism in the Perm Krai]. Vestnik Udmurtskogo universiteta. Seriya: Biologiya. Nauki o zemle, 2013, no. 4, pp. 146-153.

9. Oborin M.S. Metodologicheskie aspekty provedeniya sistemnogo analiza i klasterizatsii rynka sanatorno-kurortnykh uslug [Methodological Aspects of System Analysis and Clustering of the SanatoriumResort Services Market]. Nauchnye vedomosti Belgorodskogo gosudarstvennogo universiteta. Seriya: Ekonomika. Informatika, 2015, no. 19 (216), pp. 43-51.

10. Reyting regionov $R F$ po kachestvu zhizni2015 [Rating of Russian Regions by Life Quality - 2015]. URL: http://vid1.rian.ru/ig/ratings/life_2015.pdf.

11. Reyting regionov $R F$ po kachestvu zhizni2016 [Rating of Russian Regions by Life Quality - 2016]. URL: http://vid1.rian.ru/ig/ratings/life_2016.pdf.

12. Reyting regionov $R F$ po kachestvu zhizni2017 [Rating of Russian Regions by Life Quality - 2017]. URL: http://vid1.rian.ru/ig/ratings/life_2017.pdf.

13. Strategiya sotsialno-ekonomicheskogo razvitiya Krasnodarskogo kraya na dolgosrochnyy period, versiya 1.1 (polnaya) [Strategy of Social and Economic Development of the Krasnodar Krai for a Long-Term Period, Version 1.1 (Complete)]. URL: http:/ /mprkk.ru/media/main/attachment/attach/ proekt_strategii.pdf.

14. Yakovleva-Chernysheva A.Yu. Osobennosti klasternogo vzaimodeystviya v sanatorno-kurortnoy sfere [Features of Cluster Interaction in the SanatoriumResort Sphere]. Upravlenie i ekonomika v XXI veke, 2014, no. 2, pp. 23-29. 


\section{Information about the Authors}

Matvey S. Oborin, Doctor of Sciences (Economics), Professor, Department of Economic Analysis and Statistics, Perm Institute (Branch) of Russian Economic University named after G.V. Plekhanov, Gagarina Boulevard, 57, 614070 Perm, Russian Federation; Professor of Department of World and Regional Economy, Economic Theory, Perm State National Research University, Bukireva St., 15, 614990 Perm, Russian Federation; Professor of Department of Management, Perm State Agro-Technological University named after Academician D.N. Pryanishnikov, Petropavlovskaya St., 23, 614990 Perm, Russian Federation; Professor of Department of Management and Technologies in Tourism and Service, Sochi State University, Sovetskaya St., 26a, 354000 Sochi, Russian Federation, recreachin@rambler.ru, https:/ /orcid.org/0000-0002-4281-8615

Svetlana Yu. Tsekhla, Doctor of Sciences (Economics), Professor, Head of Department of Business Management, Institute of Economics and Management, Crimean Federal University named after V.I. Vernadsky, Prosp. Akademika Vernadskogo, 4, 295007 Simferopol, Russian Federation, svetlana.tsohla@gmail.com, https://orcid.org/0000-0001-6485-3019

\section{Информация об авторе}

Матвей Сергеевич Оборин, доктор экономических наук, профессор, профессор кафедры экономического анализа и статистики, Пермский институт (филиал) Российского экономического университета им. Г.В. Плеханова, Бульвар Гагарина, 57, 614070 г. Пермь, Российская Федерация; профессор кафедры мировой и региональной экономики, экономической теории, Пермский государственный национальный исследовательский университет, ул. Букирева, 15, 614990 г. Пермь, Российская Федерация; профессор кафедры менеджмента, Пермский государственный аграрнотехнологический университет им. ак. Д.Н. Прянишникова, ул. Петропавловская, 23, 614990 г. Пермь, Российская Федерация; профессор кафедры управления и технологий в туризме и сервисе, Сочинский государственный университет, ул. Советская, 26a, 354000 г. Сочи, Российская Федерация, recreachin@rambler.ru, https://orcid.org/0000-0002-4281-8615

Светлана Юрьевна Цехла, доктор экономических наук, профессор, заведующая кафедрой менеджмента предпринимательской деятельности, Институт экономики и управления Крымского федерального университета им. В.И. Вернадского, просп. Академика Вернадского, 4, 295007 г. Симферополь, Российская Федерация, svetlana.tsohla@gmail.com, https:/orcid.org/0000-0001-6485-3019 